\title{
Criminal Cases Related to Slovak Citizens at the Court of Justice of the European Union'
}

\author{
Libor Klimek * \\ Eva Szabová ** \\ Simona Ferenčíková *** \\ DOI: https://doi.org/10.24040/sap.2021.8.4.268-302
}

\begin{abstract}
:
KLIMEK, Libor - SZABOVÁ, Eva - FERENČÍKOVÁ, Simona: Criminal Cases Related to Slovak Citizens at the Court of Justice of the European Union. The Slovak Republic is a Member State of the European Union. As regards its national criminal law, it has constantly been influenced by the European Union law. Not only legislation (primary as well as secondary), but also case-law of the Court of Justice of the European Union (formerly known as the Court of Justice of the European Union) shall be accepted in the Member States, including the Slovak Republic. As regards case-law, some proceedings before the Court of Justice have been connected to Slovak citizens, in particular citizens staying in another States and committing criminal offence(s). The objective of the work is the assessment of case-law of the Court of Justice as regards Slovak citizens within criminal cases. It is divided into four sections. The first section analyses case C-491/07 - Vladimir Turanský. The second section analyses case C-289/15 - Jozef Grundza. The third section analyses case C-603/19 - TG and UF. The fourth section analyses case C-495/18, $Y X$.
\end{abstract}

\section{Key words:}

criminal cases, Slovak citizens, case-law, Court of Justice of the European Union, case C-491/07 - Vladimir Turanský, case C-289/15 - Jozef Grundza, case C-603/19 - TG and $U F$, case C-495/18, YX

1 The contribution was elaborated as a part of the research project VEGA No. 1/0004/20 'Implementation of Mutual Recognition of Judicial Decisions in Criminal Matters into the Legal Order of the Slovak Republic' [Slovak: Zavedenie vzájomného uznávania justičných rozhodnutí v trestných veciach do právneho poriadku Slovenskej republiky], funded by the Scientific Grant Agency of the Ministry of Education, Science, Research and Sport of the Slovak Republic and the Slovak Academy of Sciences. The funding was awarded to the Matej Bel University in Banská Bystrica, Slovak Republic.

* doc. JUDr. et PhDr. mult. Libor Klimek, PhD. Associate Professor at the Department of Criminal Law, director of the Criminology and Criminalistics Research Centre at the Faculty of Law, Matej Bel University in Banská Bystrica, Slovak Republic. Visiting Professor at the Faculty of Law, Leipzig University, Germany; ORCID: https://orcid.org/0000-0003-3826-475X.

** doc. JUDr. Eva Szabová, PhD. Associate Professor and head of the Department of Criminal Law and Criminology at the Faculty of Law, Trnava University in Trnava, Slovak Republic.

*** doc. JUDr. Simona Ferenčíková, PhD. Associate Professor at the Department of Criminal Law at the Faculty of Law, Pavol Jozef Šafárik University in Košice, Slovak Republic. 


\section{Introduction}

In the pre-Lisbon era, i.e. until November 2009, the Court of Justice of the European Union shall have jurisdiction to give preliminary rulings on the validity and interpretation of framework decisions [...]. ${ }^{1}$ The reference to the Court of Justice for a preliminary ruling shall be subjected to the condition that the national court considers that a decision on the question is necessary in order to enable it to give judgment.

Nowadays, in the Lisbon era, i.e. from December 2009, with respect to acts of the European Union in the field of judicial co-operation in criminal matters which have been adopted before the entry into force of the Treaty of Lisbon, the framework decisions (among others), the powers of the Court of Justice shall remain the same. ${ }^{2}$

The objective of the work is the assessment of case-law of the Court of Justice of the European Union as regards Slovak citizens within criminal cases. In each following section at the outset is emphasised the subject matter of the analysed case. As a starting point for further analysis, one may usefully look the dispute in the proceedings. There are introduced questions(s) referred to the Court of Justice. Each analysis is concluded by the Court's rulings.

\section{Judgment of 22 December 2008 - Case C-491/07, Vladimir Turanský}

\subsection{Reference for a Preliminary Ruling}

This reference for a preliminary ruling concerns the interpretation of Article 54 of the Convention implementing the Schengen Agreement of 1985 on the gradual abolition of checks at their common borders signed in Schengen (Luxembourg) in 19903 (hereinafter the "Convention Implementing the Schengen Agreement").

The reference was made in criminal proceedings instituted in Austria on 23 November 2000 against Mr. Turanský, a Slovak national suspected of having carried out, along with others, a serious robbery on an Austrian national in the territory of the Republic of Austria.

1 Article 35(1) of the Treaty on European Union as amended by the Treaty of Amsterdam. Official Journal of the European Communities, C 340 of 10 November 1997; Article 35(1) of the Treaty on European Union as amended by the Treaty of Nice. Official Journal of the European Union, C 321/E/5 of 29 December 2006.

2 Article 10(1) the Protocol (No 36) on transitional provisions, annexed to the Treaty on European Union and to the Treaty on the functioning of the European Union. Official Journal of the European Union, C 83/322 of 30 March 2010.

3 Convention Implementing the Schengen Agreement of 14 June 1985 between the Governments of the States of the Benelux Economic Union, the Federal Republic of Germany and the French Republic on the gradual abolition of checks at their common borders. Official Journal of the European Communities, C 239/19 of 22 September 2000. 


\subsection{Dispute in the Main Proceedings and the Question Referred for a Preliminary Ruling}

Mr. Turanský is suspected of having - on 5 October 2000, in the company of two Polish nationals who are being prosecuted separately - robbed a person of a sum of money belonging to him at his home in Vienna (Austria), and of thereafter seriously injuring him.

On 23 November 2000, Austrian Public Prosecutor in Vienna (Staatsanwaltschaft Wien) therefore requested the investigating judge attached to the referring court to open a preliminary investigation concerning Mr. Turanský, who was strongly suspected of serious robbery under the Austrian Criminal Code, and to issue an arrest warrant and an alert for his arrest.

On 15 April 2003, having been informed that Mr. Turanský could be found in his country of origin, the Republic of Austria, in accordance with Article 21 of the European Convention on Mutual Assistance in Criminal Matters, requested the Slovak Republic to reopen proceedings against him.

Since the Slovak authorities approved that request, the investigating judge attached to the referring court stayed the criminal proceedings pending the final decision of those authorities.

On 26 July 2004, the police officer in Prievidza (Slovakia) in charge of the investigation opened criminal proceedings into the reported acts without however at the same time charging a specific person. In the course of that investigation, Mr. Turanský was heard as a witness.

By letter of 20 December 2006, the Prosecutor General of the Slovak Republic notified the Austrian authorities of a decision of the District Police Headquarters in Prievidza (Okresné riaditel'stvo Policajného zboru Prievidza) of 14 September 2006, ordering the suspension under Article 215(1)(b) of the Code of Criminal Procedure (Trestny poriadok) of the criminal proceedings relating to the alleged robbery. In that decision, the Prievidza police officer in charge of the investigation wrote: 'Under Article 215(1)(b) of the Code of Criminal Procedure, I order, with regard to the criminal proceedings concerning the case of robbery in concert with others, the suspension of the proceedings since the act does not constitute a crime and there is no reason to continue the case. ... That has also been proved by the statements of the victim ... and the statements of the witness [Turanský]. This means that Mr. Turanský's act did not constitute the crime of robbery ... Even if one had to take into account the act of not preventing the crime ..., it would likewise no longer be possible to continue the proceedings ... with the objective of issuing formal charges, since prosecution would not be permitted in the present case, owing to expiry of the limitation period.

A complaint, having suspensive effect, could be brought against that decision within a period of three days following the date on which it was pronounced. No such complaint was however made.

The Regional Court for Criminal Matters (Landesgericht für Strafsachen) in Vienna has doubts whether the decision to suspend the criminal proceedings, taken by a Slovak police authority in an investigation into the same acts as those on which the proceedings pending before it are based, can give rise to the application of Article 54 
of the Convention Implementing the Schengen Agreement and, therefore, preclude the continuation of the pending proceedings.

Since it has to rule on the question whether the decision of the Slovak police authority of 14 September 2006 precludes the investigating judge from continuing the preliminary proceedings which were stayed in the Republic of Austria, the referring court decided to stay the proceedings and to refer the following question to the Court for a preliminary ruling - Must the bar on a second prosecution for the same acts (ne bis in idem principle) contained in the Convention Implementing the Schengen Agreement be interpreted as precluding the prosecution of a suspect in the Republic of Austria when criminal proceedings instituted in the Slovak Republic in respect of the same acts, after its accession to the European Union, were discontinued after a police authority, following an examination of the merits of the case and without further sanction, terminated them with immediate effect by ordering their suspension? ${ }^{4}$

\subsection{Consideration of the Question by the Court of Justice}

By this question, the referring court asks, essentially, whether the ne bis in idem principle enshrined in Article 54 of the Convention Implementing the Schengen Agreement applies to a decision such as that at issue in the main proceedings, whereby a police authority, after examining the merits of the case brought before it, makes an order, at a stage before the charging of a person suspected of a crime, suspending the criminal proceedings which had been instituted.

It is clear from the very wording of Article 54 of the Convention Implementing the Schengen Agreement that no one may be prosecuted in a Contracting State for the same acts as those in respect of which his trial has been 'finally disposed of' in another Contracting State.

With regard to the concept of 'finally disposed of', the Court has already declared, first, in paragraph 30 of joined cases C-187/01 and C-385/01, Gözütok \& Brügge, that when, following criminal proceedings, further prosecution is definitively barred, the person concerned must be regarded as someone whose trial has been 'finally disposed of' for the purposes of Article 54 of the Convention Implementing the Schengen Agreement in relation to the acts which he is alleged to have committed.

Second, it has held in paragraph 61 of case C-150/05, Van Straaten, that Article 54 of the Convention Implementing the Schengen Agreement applies to a decision of the judicial authorities of a Contracting State by which the accused is finally acquitted for lack of evidence.

It follows that, in principle, a decision must, in order to be considered as a final disposal for the purposes of Article 54 of the Convention Implementing the Schengen Agreement, bring the criminal proceedings to an end and definitively bar further prosecution.

4 Reference for a preliminary ruling from the Regional Court for Criminal Matters (Landesgericht für Strafsachen) (Austria), lodged on 31 October 2007 - Criminal proceedings against Vladimír Turanský (Case C-491/07). 
In order to assess whether a decision is 'final' for the purposes of Article 54 of the Convention Implementing the Schengen Agreement, it is necessary first of all to ascertain, as contended by the Austrian, Netherlands, Finnish and United Kingdom Governments and by the Commission, that the decision in question is considered under the law of the Contracting State which adopted it to be final and binding, and to verify that it leads, in that State, to the protection granted by the ne bis in idem principle.

A decision which does not, under the law of the first Contracting State which instituted criminal proceedings against a person, definitively bar further prosecution at national level cannot, in principle, constitute a procedural obstacle to the opening or continuation of criminal proceedings in respect of the same acts against that person in another Contracting State.

With regard more specifically to the definitive character, under Slovak law, of the decision in question in the main proceedings, it should be pointed out, as is moreover clear from the observations of the Netherlands Government and the Commission, that Article 57 of the Convention Implementing the Schengen Agreement has put in place a co-operation mechanism which allows the competent authorities of the second Contracting State to request relevant legal information from the authorities of the first State, in order to clarify, for example, the precise nature of a decision adopted in the territory of the first State.

That co-operation mechanism, which was however not activated in the main proceedings, would have made it possible to establish that, in fact, a decision such as that in question in the main proceedings was not, under Slovak law, of such a nature that it must be regarded as having definitively barred further prosecution at national level.

In that regard, it emerges clearly from the written observations of the Slovak Government in the present case that a decision ordering the suspension of the criminal proceedings at a stage before a particular person is charged, taken under Article 215(1) (b) of the Slovak Code of Criminal Procedure, does not, under national law, preclude the institution of new criminal proceedings in respect of the same acts in the territory of the Slovak Republic.

Therefore, it must be held that a decision of a police authority such as that in question in the main proceedings which, while suspending the criminal proceedings, does not under the national law concerned definitively bring the prosecution to an end, cannot constitute a decision which would make it possible to conclude that the trial of that person has been 'finally disposed of' within the meaning of Article 54 of the Convention Implementing the Schengen Agreement.

That interpretation of Article 54 of the Convention Implementing the Schengen Agreement is compatible with the objective of the article, which is to ensure that a person whose trial has been finally disposed of is not prosecuted for the same acts in the territory of several Contracting States on account of his having exercised his right to freedom of movement (see, to that effect, joined cases C-187/01 and C-385/01, Gözütok \& Brügge, paragraph 38).

The application of that article to a decision to suspend criminal proceedings such as that taken in the main proceedings would have the effect of precluding, in another Contracting State, in which more evidence may be available, any possibility of prosecuting and perhaps punishing a person on account of his unlawful conduct, even though 
such a possibility is not ruled out in the first Contracting State, in which the trial of the person is not considered to have been finally disposed of under national law.

Such an outcome would, as pointed out by the Swedish and United Kingdom Governments in their written observations, be contrary to the very purpose of the provisions of Title VI of the Treaty on European Union as stated in the fourth indent of the first paragraph of Article 2 thereof, that is, to take 'appropriate measures with respect to ... prevention and combating of crime' while developing the Union as an area of freedom, security and justice in which the free movement of persons is assured.

It should be added that, while the goal of Article 54 of the Convention Implementing the Schengen Agreement is to ensure that a person, once he has been found guilty and served his sentence, or, where applicable, been acquitted by a final judgment in a Member State, may travel within the Schengen territory without fear of being prosecuted for the same acts in another contracting State (see, to that effect, case C-436/04, Van Esbroeck, paragraph 34), it is not intended to protect the suspect from having to submit to possible subsequent investigations, in respect of the same acts, in several Contracting States.

In the light of the foregoing, the answer to the question referred must be that the ne bis in idem principle enshrined in Article 54 of the Convention Implementing the Schengen Agreement does not fall to be applied to a decision by which an authority of a Contracting State, after examining the merits of the case brought before it, makes an order, at a stage before the charging of a person suspected of a crime, suspending the criminal proceedings, where the suspension decision does not, under the national law of that State, definitively bar further prosecution and therefore does not preclude new criminal proceedings, in respect of the same acts, in that State.

\subsection{Rulings}

The Court of Justice in answer to the questions referred to it rules - the ne bis in idem principle enshrined in Article 54 of the Convention Implementing the Schengen Agreement, does not fall to be applied to a decision by which an authority of a Contracting State, after examining the merits of the case brought before it, makes an order, at a stage before the charging of a person suspected of a crime, suspending the criminal proceedings, where the suspension decision does not, under the national law of that State, definitively bar further prosecution and therefore does not preclude new criminal proceedings, in respect of the same acts, in that State.

\section{Judgment of 11 January 2017 - Case C-289/15, Jozef Grundza}

\subsection{Reference for a Preliminary Ruling}

The request for a preliminary ruling concerns the interpretation of Articles 7(3) and $9(1)(d)$ of the Framework Decision 2008/909/JHA on the application of the principle of mutual recognition to judgments in criminal matters imposing custodial sentences or measures involving deprivation of liberty for the purpose of their enforcement in 
the $\mathrm{EU}^{5}$ (hereinafter the "Framework Decision 2008/909/JHA on mutual recognition of custodial sentences and deprivation of liberty"); its unofficial name is the Framework Decision 2008/909/JHA on the transfer of prisoners ${ }^{6}$.

The request has been made in proceedings concerning the recognition of a criminal judgment and the enforcement, in Slovakia, of a custodial sentence imposed by a Czech court on Mr. Jozef Grundza.

\subsection{Dispute in the Main Proceedings and the Question Referred for a Preliminary Ruling}

On 3 October 2014, Czech District Court in Cheb (Okresní soudv Chebu) imposed a cumulative custodial sentence of 15 months on Mr. Grundza, a Slovak national, for burglary and obstruction of the implementation of a decision of a public body, namely breach of a temporary ban on driving imposed on him by decision of the Municipality of Přerov (Magistrát mesta Přerov) on 12 February 2014.

The judgment of 3 October 2014, together with the certificate referred to in Annex I to the Framework Decision 2008/909/JHA on mutual recognition of custodial sentences and deprivation of liberty, was sent to Slovak Regional Court in Prešov (Krajský súd v Prešove) for the purpose of recognition of the judgment and enforcement of the sentence in Slovakia.

In its order for reference, that court states that the offences at issue in the main proceedings were not regarded by the judicial body of the issuing State, namely the Czech Republic, as offences for the purposes of Article 7(1) of the Framework Decision 2008/909/JHA on mutual recognition of custodial sentences and deprivation of

5 Council Framework Decision 2008/909/JHA of 27 November 2008 on the application of the principle of mutual recognition to judgments in criminal matters imposing custodial sentences or measures involving deprivation of liberty for the purpose of their enforcement in the European Union as amended by the Framework Decision 2009/299/JHA. Official Journal of the European Union L 327/27 of 5 December 2008. Details see, for example: KLIMEK, L. Mutual Recognition of Judicial Decisions in European Criminal Law. Cham : Springer, 2017, 742 pages.

6 See, for example: European Commission (2014): 'Report from the Commission to the European Parliament and the Council on the implementation by the Member States of the Framework Decisions 2008/909/JHA, 2008/947/JHA and 2009/829/JHA on the mutual recognition of judicial decisions on custodial sentences or measures involving deprivation of liberty, on probation decisions and alternative sanctions and on supervision measures as an alternative to provisional detention', $\operatorname{COM}(2014) 57$ final, p. 3; European Commission (2014): 'Tables State of play and Declarations accompanying the document Report from the Commission to the European Parliament and the Council on the implementation by the Member States of the Framework Decisions 2008/909/JHA, 2008/947/JHA and 2009/829/JHA on the mutual recognition of judicial decisions on custodial sentences or measures involving deprivation of liberty, on probation decisions and alternative sanctions and on supervision measures as an alternative to provisional detention', Commission staff working document, $\operatorname{SWD(2014)} 34$ final, p. 3; Council of the European Union (2014): 'Council Framework Decision 2008/909/ JHA', 9885/14, p. 1. 
liberty, so that enforcement of the 15-month cumulative sentence is subject to it being established that the acts covered by the judgment of 3 October 2014 also constitute offences under Slovak law.

That court is in some doubt as to whether the condition of double criminality is met with regard to the act described as 'the offence of thwarting the implementation of the decision of a public authority'.

The referring court states in that regard that Article 348(1)(d) of the Slovak Criminal Code (Trestný zákon), which concerns the offence of thwarting the implementation of an official decision, refers only to decisions of the judicial authorities or of another 'Slovak' body which are enforceable in 'Slovak territory'.

Thus, according to the referring court, it is clear from the assessment of the act for which Mr. Grundza was convicted in the Czech Republic that that act does not in fact constitute an 'offence' for the purposes of Article 348(1)(d) of the Slovak Criminal Code, as it does not correspond to the factual constituent elements of the offence of thwarting the implementation of an official decision within the meaning of that provision. Mr. Grundza was convicted of thwarting a decision adopted by a body of the Czech Republic, a decision which has effect only in the territory of that Member State.

The referring court is also uncertain whether, having regard to the purpose of the Framework Decision 2008/909/JHA on mutual recognition of custodial sentences and deprivation of liberty, namely to facilitate the social rehabilitation of a sentenced person by, inter alia, developing co-operation between Member States when enforcing criminal judgments, in a case such as that in the main proceedings, in which an interest protected by the legal order of the issuing State has been infringed, it may not be necessary to examine double criminality in abstracto, that is, as if an interest protected under the legal system of the executing State had been infringed.

In those circumstances, the Regional Court in Prešov (Krajský súd v Prešove) decided to stay the proceedings and to refer the following question to the Court of Justice for a preliminary ruling: - On a proper interpretation of Articles 7(3) and 9(1)(d) of the Framework Decision 2008/909/JHA on mutual recognition of custodial sentences and deprivation of liberty, is the condition of double criminality to be considered satisfied only where the act to which the decision to be recognised refers constitutes an offence in concreto, i.e. on the basis of a concrete assessment of the facts (whatever its constituent elements or however it is described) also in the law of the executing State, or is that condition sufficiently satisfied where the act generally constitutes (in abstracto) an offence also in the legal order of the executing State? ${ }^{7}$

\subsection{Consideration of the Question by the Court of Justice}

By its question, the referring court seeks to ascertain, in essence, whether Articles 7(3) and 9(1)(d) of the Framework Decision 2008/909/JHA on mutual recognition of custodial sentences and deprivation of liberty are to be interpreted as meaning that the condition of double criminality is met in a situation, such as that in the main proceedings,

7 Request for a preliminary ruling from the District Court in Prešov (Krajský súd v Prešove) (Slovak Republic) lodged on 15 June 2015 - Jozef Grundza (Case C-289/15). 
in which recognition of a judgment and enforcement of a sentence are sought in respect of acts which are classified in the issuing State as a 'criminal offence consisting in thwarting the implementation of an official decision committed in the territory of the issuing State', and for which a criminal offence, similarly classified, exists in the law of the executing State, but a national rule of the executing State requires, for such an offence to occur, the official decision to have been issued by one of the authorities operating in its own territory.

It should be noted at the outset that, for the purpose of providing a useful answer to that question, it is not appropriate to base the analysis on an in concreto or an in abstracto assessment of the condition of double criminality.

It should be observed in that regard, first, that the Framework Decision 2008/909/ JHA on mutual recognition of custodial sentences and deprivation of liberty, which is an instrument providing for a minimal level of harmonisation, and in particular Article 7 thereof, which concerns the condition of double criminality, makes no mention of those notions.

Second, Member States have adopted different positions as regard the precise meaning of those notions in the context of double criminality.

For the purpose of answering the question thus reformulated, it should be recalled that, under Article 7(3) of the Framework Decision 2008/909/JHA on mutual recognition of custodial sentences and deprivation of liberty, with regard to offences other than those included in the list of 32 offences set out in Article 7(1), it is open to the executing State to make recognition of the judgment and enforcement of the sentence subject to the condition that it relates to acts which also constitute an offence under the law of the executing State, whatever its constituent elements or however it is described. In other words, that provision allows the executing State to make recognition of the judgment and enforcement of the sentence subject to the requirement that the condition of double criminality is met.

Correspondingly, Article 9 of the Framework Decision 2008/909/JHA on mutual recognition of custodial sentences and deprivation of liberty, concerning grounds for non-recognition and non-enforcement, provides in paragraph 1(d) thereof that it is possible for the competent authority of the executing State to refuse to recognise the judgment handed down in the issuing State and to enforce the sentence imposed in that State if the condition of double criminality is not met.

It is apparent from the order for reference that the acts for which Mr. Grundza was convicted, in particular the thwarting of the implementation of a decision of a public authority, were not regarded by the competent authority of the issuing State, namely the Czech Republic, as offences falling within Article 7(1) of the Framework Decision 2008/909/JHA on mutual recognition of custodial sentences and deprivation of liberty.

Accordingly, in accordance with Article 7(3) of the Framework Decision 2008/909/ JHA on mutual recognition of custodial sentences and deprivation of liberty, the recognition of the judgment of 3 October 2014 and enforcement of the 15-month cumulative sentence are subject to the competent Slovak authority finding that the acts covered by that judgment also constitute an offence under Slovak law, whatever its constituent elements or however it is described in the issuing State. 
That having been established, it should be noted that it is that Court's established case-law that, in interpreting a provision of EU law, it is necessary to consider not only its wording, but also the context in which it occurs and the objectives pursued by the rules of which it forms part (judgment in case C-237/15 PPU, Lanigan, para. 35, and in case C-554/14, Ognyanov, para. 31).

With regard, first, to the wording of Article 7(3) of the Framework Decision 2008/909/JHA on mutual recognition of custodial sentences and deprivation of liberty, it should be noted, that that provision circumscribes the scope of the assessment of double criminality in that it requires the competent authority of the executing State to verify whether the acts in question 'also constitute an offence' under the national law of that State, 'whatever its constituent elements or however it is described'.

As is apparent from the very wording of Article 7(3) of the Framework Decision 2008/909/JHA on mutual recognition of custodial sentences and deprivation of liberty, the necessary and sufficient condition for the purpose of assessing double criminality resides in the fact that the acts giving rise to the sentence imposed in the issuing State also constitute an offence in the executing State. It follows that the offences do not need to be identical in the two Member States concerned.

That interpretation is borne out by the words 'whatever [the] constituent elements' of the offence as laid down in the executing State and 'however it is described', which make it clear, that there does not have to be an exact match between the constituent elements of the offence, as defined in the law of the issuing State and the executing State, respectively, or between the name given to or the classification of the offence under the national law of the respective States.

Accordingly, that provision advocates a flexible approach by the competent authority of the executing State when assessing the condition of double criminality, both as regards the constituent elements of the offence and its description.

Thus, the relevant factor when assessing double criminality, for the purposes of Article 7(3) of the Framework Decision 2008/909/JHA on mutual recognition of custodial sentences and deprivation of liberty, are that $(i)$ the factual elements underlying the offence, as reflected in the judgment handed down in the issuing State, and (ii) how the offence is defined under the law of the executing State, should be congruent.

It follows from the foregoing considerations that, when assessing double criminality, the competent authority of the executing State is required to verify whether the factual elements underlying the offence, as reflected in the judgment handed down by the competent authority of the issuing State, would also, per se, be subject to a criminal penalty in the executing State if they were present in that State.

Second, the context of Article 7(3) and Article 9(1)(d) of the Framework Decision 2008/909/JHA on mutual recognition of custodial sentences and deprivation of liberty also militates in favour of such an assessment of double criminality.

It should be observed that, as provided for in Article 26 thereof, the Framework Decision 2008/909/JHA on mutual recognition of custodial sentences and deprivation of liberty replaces, as regards relations between Member States, a number of instruments of international law in order to further develop co-operation, as stated in Recital No. 5 of the decision, in the enforcement of criminal judgments. 
Unlike those instruments of international law, the Framework Decision 2008/909/ JHA on mutual recognition of custodial sentences and deprivation of liberty is based primarily on the principle of mutual recognition, which constitutes, as stated in Recital No. 1 of the decision, read in the light of Article 82(1) the Treaty on the Functioning of the European Union ${ }^{8}$, the 'cornerstone' of judicial co-operation in criminal matters within the European Union, which, according to Recital No. 5 of the decision, is founded on a special mutual confidence of the Member States in their respective legal systems (see, to that effect, judgment in case C-554/14, Ognyanov, paragraphs 46 and 47$)$.

The principle of mutual recognition means, in accordance with Article 8(1) of the Framework Decision 2008/909/JHA on mutual recognition of custodial sentences and deprivation of liberty, that, in principle, the competent authority of the executing State is to recognise a judgment which has been forwarded to it and forthwith take all the necessary measures for the enforcement of the sentence.

The principle of mutual recognition has led to, among other things, the establishment, in Article 7(1) of the Framework Decision 2008/909/JHA on mutual recognition of custodial sentences and deprivation of liberty, of a list of criminal offences in respect of which the review of the condition of double criminality has been done away with.

Moreover, it should be noted that, even as regards offences which do not appear on that list, Article 7(3) of the Framework Decision 2008/909/JHA on mutual recognition of custodial sentences and deprivation of liberty merely provides Member States with the option of making recognition of a judgment and enforcement of a sentence subject to the requirement that the condition of double criminality be met.

In that context, that option enables Member States, to decline to recognise a judgment and enforce a sentence in respect of conduct which they do not consider to be morally wrong and which does not, therefore, constitute an offence.

It follows from the foregoing considerations that the condition of double criminality is an exception to the general rule of recognition of judgments and enforcement of sentences. Accordingly, the scope of the grounds for refusing to recognise a judgment or enforce a sentence, on the basis of lack of double criminality, as provided for in Article 9(1)(d) of the Framework Decision 2008/909/JHA on mutual recognition of custodial sentences and deprivation of liberty, must be interpreted strictly in order to limit cases of non-recognition and non-enforcement.

Accordingly, the purpose of the assessment of double criminality by the competent authority of the executing State, to which Article 7(3) of the Framework Decision 2008/909/JHA on mutual recognition of custodial sentences and deprivation of liberty refers, is to verify whether the factual elements underlying the offence, as reflected in the judgment handed down by the competent authority of the issuing State, would also, per se, be subject to a criminal penalty in the territory of the executing State if they were present there.

In that regard, the referring court has stated that the offence at issue in the main proceedings constitutes an infringement of an official decision adopted by a Czech

8 Treaty on the Functioning of the European Union as amended by the Treaty of Lisbon. Official Journal of the European Union, C 83/47 of 30 March 2010. 
public body and, therefore, an infringement of an interest protected by the Czech Republic, so that the condition of double criminality cannot, in any event, be considered to have been met.

Nevertheless, in assessing double criminality, the competent authority of the executing State must ascertain, not whether an interest protected by the issuing State has been infringed, but whether, in the event that the offence at issue were committed in the territory of the executing State, it would be found that a similar interest, protected under the national law of that State, had been infringed.

Third, it should be recalled that Article 3(1) of the Framework Decision 2008/909/ JHA on mutual recognition of custodial sentences and deprivation of liberty states that the purpose of that decision is to establish the rules under which a Member State, with a view to facilitating the social rehabilitation of the sentenced person, is to recognise a judgment and to enforce a sentence.

A strict interpretation of Article 9(1)(d) of the Framework Decision 2008/909/JHA on mutual recognition of custodial sentences and deprivation of liberty contributes to the attainment of that objective of facilitating the social rehabilitation of the sentenced person, inter alia in a situation, such as that in the main proceedings, in which that person is a national of the executing State.

In this instance, it is apparent from the documents submitted to the Court that $\mathrm{Mr}$. Grundza was convicted by the competent Czech judicial authority for, among other things, driving a motor vehicle in the territory of that Member State notwithstanding the fact that he had been banned from so doing by a decision issued by a Czech public authority.

For the purpose of determining whether the condition of double criminality was met in the proceedings before it, the referring court, which is called upon to recognise and enforce the sentence, is thus required to ascertain whether, in the event that those factual elements - that is, the driving of a motor vehicle notwithstanding the existence a ban imposed by an official decision - were present in the territory of the Member State to which that court belongs, they would be subject to a criminal penalty under the domestic law of that State. If that is the case, it must be concluded that the condition of double criminality is met.

\subsection{Opinion of Advocate General Bobek ${ }^{9}$}

\section{A Note on Terminology}

All of the Member States that have presented observations as well as the Commission agree that the condition of double criminality is satisfied in the present case. What differs, however, is their reasoning for arriving at such a conclusion.

The question referred by the national court relies on the terminological distinction between in abstracto and in concreto assessments of the condition of double criminality.

That terminology is frequently used in criminal law doctrine. The specific and precise content of those terms (in concreto and in abstracto) is, however, less clear. It seems to be understood differently by various authors.

9 Opinion of Advocate General Bobek delivered on 28 July 2016 - Case C-289/15 - Grundza. 
When looking for a common denominator within the various definitions, it could be perhaps suggested that the assessment of double criminality in abstracto calls for verification of the question of whether the behaviour and acts referred to in the judgment of the issuing State would amount to a criminal offence if committed on the territory of the executing State.

The assessment of double criminality in concreto seems to require much more, including the satisfaction of other conditions of criminal liability as defined by the laws of the executing state, such as the age or mental state of the accused or consideration of further factual circumstances in which the act was committed.

The written submissions as well as the discussion that unfolded at the hearing demonstrate that considerable diversity exists among the Member States as to the exact understanding of the notions of in concreto and in abstracto in the context of double criminality.

That discussion also made it clear that the distinction between the assessment of double criminality in abstracto or in concreto is not a binary choice, but rather a sliding scale. That distinction is based on the level of abstraction chosen to analyse double criminality. At the highest level of abstraction, it could be argued that the focus is on the mere immorality of an act: a certain act is considered wrong in both systems. Further down, one finds the basic constituent elements of the crime. Even further down on the scale of abstraction, one may look into all the other particular elements of criminal liability, including for example the question of age, or the (non-)existence of exceptional circumstances, but also the severity of sanctions. At the lowest level of abstraction (or rather the highest level of concretisation), all the individual factual elements of the act are relevant as well. What is required there is in fact virtual identity of the act and its legal assessment under both legal systems in question.

Where then is the dividing line between in abstracto and in concreto to be drawn? Similar to the position expressed by the Commission at the hearing, I am of the view that arguing about these notions and their specific content is perhaps not entirely helpful for the purpose of providing the national court with a useful reply in this case. Moreover, in view of the diversity in the understanding of the intervening Member States of how precisely the terms in abstracto and in concreto are to be defined, attaching terminological 'stickers' might be potentially misleading, since it is bound to be understood differently.

For these reasons, rather than looking at notions, the analysis in this Opinion will be functional. I shall suggest an answer to the national court based on the operation of the double criminality condition in the context of the intra-EU system of judicial co-operation in criminal matters and under the Framework Decision 2008/909/JHA on mutual recognition of custodial sentences and deprivation of liberty in particular.

However, before embarking on that functional analysis, it is useful to briefly consider the evolution of the concept of double criminality in an international law and European law context. That evolution sharpens our understanding of what the Framework Decision 2008/909/JHA on mutual recognition of custodial sentences and deprivation of liberty was supposed to achieve. 


\section{Evolution of the Double Criminality Condition}

The requirement of double criminality generally makes the exercise of the extraterritorial jurisdiction of a State conditional on the fact that the conduct concerned is criminalised under both the law which applies in the place where the act was committed and the law of the State punishing the act. It is linked to the principle of legality and, more specifically, the foreseeability of sanctions (nulla poena sine lege).

Double criminality has been a traditional condition for extradition. Although international law instruments may list specific criminal offences that will be subject to extradition, extradition will often be subject to the additional requirement that the offence is criminalised in the legal orders of both States involved.

The double criminality requirement is embedded in the principles of sovereignty, reciprocity and non-intervention, which constitute the fundamental elements of co-operation between States enshrined in instruments of international public law. This co-operation essentially aims at avoiding interference in the domestic affairs of the States involved.

By contrast, the system of intra-EU judicial co-operation in criminal matters relies primarily on the principle of mutual recognition. Within this system, the legal orders of the different Member States are open to each other based on enhanced mutual confidence in each other's criminal justice systems.

On a more practical level, this means that once a judicial decision has been adopted in one Member State, it 'shall be recognised and executed in other Member States as quickly as possible and with as little conflict as possible, as if it was a national decision'.

The principle of mutual recognition has led to, among other things, the establishment of a list of criminal offences in respect of which the review of the condition of double criminality has been done away with and therefore shall not be conducted.

The, albeit partial, departure from the requirement of double criminality represents a qualitative shift from the practice under international public law instruments. The departure was first introduced by the Framework Decision 2002/584/JHA on the European arrest warrant and the surrender procedures between Member States ${ }^{10}$ (hereinafter the "Framework Decision 2002/584/JHA on the European arrest warrant") and has since been extended in a number of other EU law acts, including the Framework Decision 2008/909/JHA on mutual recognition of custodial sentences and deprivation of liberty.

The Framework Decision 2002/584/JHA on the European arrest warrant replaced the multilateral system of extradition previously in place between the Member States. In a similar vein, the Framework Decision 2008/909/JHA on mutual recognition of custodial sentences and deprivation of liberty has replaced several international law instruments with the aim of increasing the level co-operation between Member States.

10 Council Framework Decision 2002/584/JHA of 13 June 2002 on the European arrest warrant and the surrender procedures between Member States as amended by the Framework Decision 2009/299/JHA. Official Journal of the European Communities, L 190/1 of 18 July 2002. Details see, for example: KLIMEK, L. European Arrest Warrant. Cham - Heidelberg - New York Dordrecht - London : Springer, 2015, 375 pages, KLIMEK, L. Mutual Recognition of Judicial Decisions in European Criminal Law. Cham : Springer, 2017, 742 pages. 
The international law instruments that preceded the Framework Decision 2008/909/ JHA on mutual recognition of custodial sentences and deprivation of liberty were the Convention on the Transfer of Sentenced Persons, the Convention between the Member States of the European Communities on the Enforcement of Foreign Criminal Sentences, and the European Convention on the International Validity of Criminal Judgments. All of those instruments contained provisions on double criminality.

It is important to keep these historical dynamics in mind when considering the function of the double criminality condition in the Framework Decision 2008/909/ JHA on mutual recognition of custodial sentences and deprivation of liberty. The operation of that rule under the Framework Decision 2008/909/JHA on mutual recognition of custodial sentences and deprivation of liberty should not produce less developed or more cumbersome interactions between the Member States, compared to the previous less integrated system based on the aforementioned international law instruments.

The Operation of the Double Criminality Condition in the Context of the Framework Decision 2008/909/JHA on Mutual Recognition of Custodial Sentences and Deprivation of Liberty

By its preliminary question, the referring court enquires, in essence, about the appropriate level of abstraction or generalisation at which a criminal act attracting a sentence should be considered for the purpose of verifying the condition of double criminality under the Framework Decision 2008/909/JHA on mutual recognition of custodial sentences and deprivation of liberty. More specifically, the question aims at ascertaining whether Articles 7(3) and 9(1)(d) of the framework decision should be interpreted as meaning that the condition of double criminality is satisfied when: (a) recognition of the judgment and enforcement of the sentence are sought in respect of acts which were classified in the issuing State as the criminal offence of 'obstruction of implementation of an official decision', and when (b) a similarly described criminal offence also exists in the law of the executing State, but when (c) the law, or rather, the case-law of the executing State apparently requires, for such an offence to occur, the official decision to have been issued by one of its own authorities.

It ought to be restated at the outset that the operation of the Framework Decision 2008/909/JHA on mutual recognition of custodial sentences and deprivation of liberty and the review of double criminality depends on whether the criminal offence concerned is included in the list in Article 7(1). For the offences listed therein, the courts of the executing State are not, in principle, allowed to examine whether the condition of double criminality is satisfied when recognising the judgment and enforcing the sentence imposed in the issuing State.

The offence of obstructing the implementation of an official decision is not on that list.

Where a criminal offence is not listed in Article 7(1) of the Framework Decision 2008/909/JHA on mutual recognition of custodial sentences and deprivation of liberty, double criminality may be examined. Whether or not double criminality is examined for such offences is an option for the Member State, not an obligation. Therefore, Member States are free to decide whether they will apply the condition of double criminality to offences not listed in Article 7(1) of the Framework Decision. 
Slovakia has made use of that possibility. Accordingly, Slovak courts must verify that condition when considering requests for the transfer of persons sentenced in other Member States.

Against this background, in order to provide the referring court with useful guidance on the test applicable to the assessment of double criminality, I will first consider the relevant elements to be taken into account when making such an assessment, before turning to the specific issue of the protected State interest which arises in the present case.

\section{Elements Relevant for the Assessment of Double Criminality}

Article 7(3) of the Framework Decision 2008/909/JHA on mutual recognition of custodial sentences and deprivation of liberty defines the scope of the assessment of double criminality by requiring that the competent authority verify whether the acts concerned also constitute an offence under the law of the executing State, whatever its constituent elements or however it is described.

Two elements are worth highlighting. First, by stressing the flexible approach to be taken to the constituent elements of the criminal offence, Article 7(3) of the Framework Decision 2008/909/JHA on mutual recognition of custodial sentences and deprivation of liberty makes it clear that there does not have to be an exact match between all of the components of the crime, as defined respectively by the law of the issuing and executing Member States.

Second, by insisting on flexibility with regard to the description of the criminal offence, Article 7(3) of the Framework Decision 2008/909/JHA on mutual recognition of custodial sentences and deprivation of liberty makes it equally clear that there is no need for an exact match in the name or taxonomy of the offence between the issuing and the executing Member State.

Conversely, what Article 7(3) of the Framework Decision 2008/909/JHA on mutual recognition of custodial sentences and deprivation of liberty does highlight as being relevant, and indeed decisive, is a match between the basic factual elements of the criminal act, as reflected in the judgment of the issuing State, on the one hand, and the definition of a criminal offence provided by the law of the executing State, on the other.

The assessment of double criminality thus requires essentially two steps: (i) delocalisation which involves taking the basic characteristics of the act committed in the issuing State, and considering that act as if it had occurred in the executing State and (ii) subsumption of those basic facts under whatever fitting offence as defined by the law of the executing State.

In other words, the questions to be asked by the judicial authority of the executing State in the process of such a 'conversion' are: can the act(s) that have led to the judgment in the issuing State be subsumed under any criminal offence provided for by the criminal law of the executing State? Would such an act be considered criminally punishable per se if committed on the territory of the executing State?

When responding to these questions and defining the relevant act(s) to be converted, I am of the view that these questions ought to be considered at a relatively high level of abstraction. A match is sought between basic factual elements that the judicial authorities of the issuing State considered as being relevant for the criminal conviction of the offender and the constitutive elements of a crime as described in the criminal law of the executing State. 
Conversely, the wording of Article 7(3) of the Framework Decision 2008/909/JHA on mutual recognition of custodial sentences and deprivation of liberty ('whatever its constituent elements or however it is described') makes it clear that the match is not to be sought between the respective normative definitions of the criminal offence in the legal systems of the issuing and executing States.

Certainly, in a number of cases, it will be rather easy to find a match already at the normative level. This seems to be the case here. The criminal offence of obstructing the implementation of an official decision is defined almost identically under the Czech and Slovak Criminal Codes. In other cases, however, the criminal offence in the executing State can be construed slightly differently from the offence in the issuing State. The constitutive elements of the two offences may not be exactly the same. Or the constitutive elements can be rather similar but the offences might be called something different in the respective legal systems. Further, in criminal codes the definition of the 'initial' criminal offence may be quite narrow and it may be part of a broader category of criminal offences which ought to be read together for the purposes of the assessment of double criminality.

However, as has already been stressed, it is quite clear that the intended conversion of an offence from the issuing state to the executing state is supposed to be 'diagonal' (basic factual elements from the issuing State being subsumed under the laws of the executing State), not 'horizontal' (whereby a match would be sought between the normative definitions of an offence in both States).

To provide a more concrete example, in the present case of Mr. Grundza, what is supposed to be converted is the basic description of the act, which could be simply captured as: the act of a person driving a motor vehicle despite the existence of an official decision prohibiting such conduct.

Next, the question is: would such an act also be punishable under the laws of the executing State, if committed on its territory? In the Slovak context, the answer appears to be in the affirmative.

However, delocalisation and subsumption might in general go even further, so as to amount to changes in the taxonomy of the offence under the laws of the executing State. The example given by the Czech Government at the hearing provides a useful illustration in this regard. It concerns the criminal offence of 'driving without a licence' in the German Criminal Code. (19) It seems that, under German criminal law, the act committed by Mr. Grundza would potentially not be classified as 'obstructing the implementation of an official decision', but as 'driving without a licence'. However, even if that were the case, in my point of view, the condition of double criminality under Article 7(3) of the Framework Decision 2008/909/JHA on mutual recognition of custodial sentences and deprivation of liberty would still be satisfied. Changes in the criminal law taxonomy are expressly foreseen and authorised by the wording of that provision when converting criminal offences from one legal system to another.

In other words, in my view, the approach that should be adopted to the assessment of double criminality under the Framework Decision 2008/909/JHA on mutual recognition of custodial sentences and deprivation of liberty relies on generalising at a higher level of abstraction the conduct that was considered and sentenced by the court of the issuing State. That generalisation necessarily implies some flexibility in the process 
of conversion during which the act concerned is examined by reference to the various available definitions of criminal offences in the executing State.

Furthermore, the suggestion that the assessment of double criminality necessitates a considerable level of abstraction is also confirmed by the rather limited scope of information that is provided by the competent authorities of the issuing State on the standardised form in Annex I to the Framework Decision 2008/909/JHA on mutual recognition of custodial sentences and deprivation of liberty.

The level of information to be provided depends on whether the request for recognition of the judgment and enforcement of the sentence concern criminal offences listed in Article 7(1) [points 1 and 2 of subsection (h) of Annex I to the Framework Decision 2008/909/JHA on mutual recognition of custodial sentences and deprivation of liberty] or whether the request concerns other (non-listed) offences [points 1 and 3 of subsection (h) of Annex I to the Framework Decision 2008/909/JHA].

However, even for the non-listed offences that can be subject to the review of double criminality, the standardised information to be provided is quite basic. As the Swedish Government noted in its written submissions, such a limited amount of information would certainly not permit a fuller assessment of the case.

In sum, there can be individual differences in criminal law taxonomy but those particularities are not relevant for the purpose of the assessment of the condition of double criminality. What matters is whether the type of act, if committed on the territory of the executing Member State, would be per se criminally punishable in the executing State.

A particular emphasis should be put on the words per se punishable, as opposed to whether, if criminally prosecuted, the sentenced person would have also been found guilty and sentenced if the criminal trial were conducted under the laws of the executing State.

In this respect, I note that the objective pursued by the Framework Decision 2008/909/JHA on mutual recognition of custodial sentences and deprivation of liberty is to facilitate the social reintegration of sentenced persons by making it possible for them to serve their sentences in another Member State.

This means that the objective is the transfer of already sentenced persons and their social reintegration. It is most definitely not to start challenging final decisions or conducting anew criminal trials in the executing Member State. It is not without reason that the co-operation established by the Framework Decision 2008/909/JHA on mutual recognition of custodial sentences and deprivation of liberty may be triggered only once the trial has been conducted and the final judgment has been given in the issuing State.

Within that framework, the condition of double criminality of Article 7(3) of the Framework Decision 2008/909/JHA on mutual recognition of custodial sentences and deprivation of liberty is properly to be understood as a residual safety valve that the executing Member State may trigger in order to refuse the execution of a sentence for an act that is not per se criminalised under its own laws. In other words, a Member State cannot be obliged to recognise and to execute a sentence for behaviour which the State and its society do not consider to be morally wrong so as to be criminalised.

\section{Relevance of the Specific Protected State Interest}

As already stated above, the assessment of the double criminality condition in the context of the Framework Decision 2008/909/JHA on mutual recognition of custodial 
sentences and deprivation of liberty requires a delocalisation of facts, carried out at a high level of abstraction, and their subsumption under the criminal law of the executing State.

It is only logical that that conversion will also be carried out with regard to the particular State interest involved in the crime. For the purpose of the definition of the act to be converted, a State interest cannot be considered as the national interest of the particular State (that is, the issuing State) but rather as a State interest that will be assessed, together with other basic elements of the act concerned, under the criminal law of the executing State.

It may be readily acknowledged that in particular and rather extreme cases, there may be exceptions to an unreserved conversion of the respective State interests of the issuing and executing States. However, with regard to a vast majority of other criminal offences, including obstructing the implementation of an official decision, a system of mutual recognition can only operate if what is indeed protected is the authority of 'an official decision', and not just the 'authority of the decisions issued exclusively by the authorities of Member State X'.

This understanding of the meaning of Article 7(3) of the Framework Decision 2008/909/JHA on mutual recognition of custodial sentences and deprivation of liberty is also confirmed by two further systemic arguments.

First, I note that some of the criminal offences listed in Article 7(1) of the Framework Decision 2008/909/JHA on mutual recognition of custodial sentences and deprivation of liberty (in respect of which the double criminality condition has been removed altogether) clearly aim at protecting the specific State interest against which they are committed. These are, for example, sabotage, corruption, counterfeiting currency, facilitation of unauthorised entry and residence, forgery of administrative documents and the trafficking therein or forgery of means of payment.

Second, Article 9(1)(d) of the Framework Decision 2008/909/JHA on mutual recognition of custodial sentences and deprivation of liberty provides for the possibility to refuse the recognition of a judgment and enforcement of a sentence if the condition of double criminality is not satisfied. However, it states that ' $[\ldots]$ in relation to taxes or duties, customs and exchange, execution of a judgment may not be refused on the ground that the law of the executing State does not impose the same kind of tax or duty or does not contain the same type of rules as regards taxes, duties and customs and exchange regulations as the law of the issuing State'.

Both of those provisions corroborate, in my point of view, the conclusion that mutual recognition under the Framework Decision 2008/909/JHA on mutual recognition of custodial sentences and deprivation of liberty is supposed to transcend, in general, the particularism of Member State interests. After all, is it not precisely what mutual recognition and respect are supposed to be about?

In the light of the above, I conclude that Articles 7(3) and 9(1)(d) of the Framework Decision 2008/909/JHA on mutual recognition of custodial sentences and deprivation of liberty should be interpreted as meaning that the condition of double criminality is satisfied if recognition of the judgment and enforcement of the sentence are sought with regard to an act, which, captured at a relatively high level of abstraction, is per se criminally punishable under the laws of the executing State, irrespective of an exact match between the taxonomy used to describe that criminal offence in the legal orders of the issuing State and the executing State. 


\subsection{Rulings}

The Court of Justice in answer to the questions referred to it rules - Article 7(3) and Article 9(1)(d) of the Framework Decision 2008/909/JHA on mutual recognition of custodial sentences and deprivation of liberty, must be interpreted as meaning that the condition of double criminality must be considered to be met, in a situation such as that in the main proceedings, where the factual elements underlying the offence, as reflected in the judgment handed down by the competent authority of the issuing State, would also, per se, be subject to a criminal sanction in the territory of the executing State if they were present in that State.

\section{Judgment of 1 October 2020 - Case C-603/19, TG and UF}

\subsection{Reference for a Preliminary Ruling}

The request for a preliminary ruling concerns the interpretation of Article 325 of the Treaty on the Functioning of the European Union ${ }^{11}$, Articles 17 and 47 of the Charter of Fundamental Rights of the European Union ${ }^{12}$, Article 38(1)(h) of the Regulation (EC) No 1260/1999 laying down general provisions on the Structural Funds ${ }^{13}$, read in conjunction with the Regulation (EC) No 1681/94 concerning irregularities and the recovery of sums wrongly paid in connection with the financing of the structural policies and the organization of an information system in this field ${ }^{14}$ (hereinafter the

11 Treaty on the Functioning of the European Union as amended by the Treaty of Lisbon. Official Journal of the European Union, C 83/47 of 30 March 2010.

12 Charter of Fundamental Rights of the European Union. Official Journal of the European Union, C 83/389 of 30 March 2010.

13 Council Regulation (EC) No 1260/1999 of 21 June 1999 laying down general provisions on the Structural Funds. Official Journal of the European Communities, L 161/1 of 26 June 1999. No longer in force - it was replaced and repealed by the Council Regulation (EC) No 1083/2006 of 11 July 2006 laying down general provisions on the European Regional Development Fund, the European Social Fund and the Cohesion Fund and repealing Regulation (EC) No 1260/1999. Official Journal of the European Union, L 210/25 of 31 July 2006. This Regulation, however, was replaced and repealed too - by the Regulation (EU) No 1303/2013 of the European Parliament and of the Council of 17 December 2013 laying down common provisions on the European Regional Development Fund, the European Social Fund, the Cohesion Fund, the European Agricultural Fund for Rural Development and the European Maritime and Fisheries Fund and laying down general provisions on the European Regional Development Fund, the European Social Fund, the Cohesion Fund and the European Maritime and Fisheries Fund and repealing Council Regulation (EC) No 1083/2006. Official Journal of the European Union, L 347/320 of 20 December 2013.

14 Commission Regulation (EC) No 1681/94 of 11 July 1994 concerning irregularities and the recovery of sums wrongly paid in connection with the financing of the structural policies and the organization of an information system in this field. Official Journal of the European Communities, L 178/43 of 12 July 1994. No longer in force - it was replaced and repealed by the Commission Regulation (EC) No 1828/2006 of 8 December 2006 setting out rules for the implementation of Council Regulation (EC) No 1083/2006 laying down general provisions on the European 
"Regulation (EC) No 1681/94 concerning irregularities and the recovery of sums"), the interpretation of the Directive 2012/29/EU establishing minimum standards on the rights, support and protection of victims of crime ${ }^{15}$ (hereinafter the "Directive 2012/29/EU on victims of crime"), Article 2 of the Regulation (EC) No 994/98 on the application of Articles 92 and 93 of the Treaty establishing the European Community to certain categories of horizontal State aid ${ }^{16}$, read in conjunction with Article 2(2) of the Regulation (EC) No 69/2001 on the application of Articles 87 and 88 Treaty establishing the European Community to de minimis aid $^{17}$, the interpretation of the Convention drawn up on the basis of the Treaty on European Union, on the protection of the European Communities' financial interests ${ }^{18}$ (hereinafter the 'Convention on the protection of the European Communities' financial interests'), and the interpretation of the Directive (EU) 2017/1371 on the fight against fraud to the Union's financial interests by means of criminal law ${ }^{19}$.

The request has been made in criminal proceedings brought against TG and UF ('the accused') for acts liable to constitute subsidy fraud funded in part from the budget of the European Union.

\subsection{Dispute in the Main Proceedings and the Questions Referred for a Preliminary Ruling}

The case in the main proceedings concerns criminal proceedings against the accused, two natural persons, for acts liable to constitute subsidy fraud funded in part from the

Regional Development Fund, the European Social Fund and the Cohesion Fund and of Regulation (EC) No 1080/2006 of the European Parliament and of the Council on the European Regional Development Fund. Official Journal of the European Union, L 371/1 of 27 December 2006.

15 Directive 2012/29/EU of the European Parliament and of the Council of 25 October 2012 establishing minimum standards on the rights, support and protection of victims of crime, and replacing Council Framework Decision 2001/220/JHA. Official Journal of the European Union, L 315/57 of 14 November 2012.

16 Council Regulation (EC) No 994/98 of 7 May 1998 on the application of Articles 92 and 93 of the Treaty establishing the European Community to certain categories of horizontal State aid. Official Journal of the European Union, L 142/1 of 14 May 1998. No longer in force - repealed and replaced by the Council Regulation (EU) 2015/1588 of 13 July 2015 on the application of Articles 107 and 108 of the Treaty on the Functioning of the European Union to certain categories of horizontal State aid. Official Journal of the European Union, L 248/1 of 24 September 2015.

17 Commission Regulation (EC) No 69/2001 of 12 January 2001 on the application of Articles 87 and 88 of the EC Treaty to de minimis aid. Official Journal of the European Communities, L 10/30 of 13 January 2001. No longer in force - valid until 31 December 2006.

18 Convention drawn up on the basis of Article K.3 of the Treaty on European Union on the protection of the European Communities' financial interests. Official Journal of the European Communities, C 316/49 of 27 November 1995.

19 Directive (EU) 2017/1371 of the European Parliament and of the Council of 5 July 2017 on the fight against fraud to the Union's financial interests by means of criminal law. Official Journal of the European Union, L 198/19 of 28 July 2017. 
budget of the European Union. The criminal offence which is the subject of the main proceedings is alleged to have been committed in the context of two calls for tenders issued in 2005 and 2006 respectively by Slovak Central Office for Labour - Social Affairs and Family (Ústredie práce sociálnych vecí a rodiny) for the submission of applications for subsidies to support job creation in micro-enterprises and job creation for disabled persons in sheltered workshops and sheltered workplaces. The first call for tenders gave entitlement to a subsidy by way of one-off assistance, whereas the second gave entitlement to a subsidy in the form of reimbursement of proven costs. The latter subsidy was $75 \%$ funded by the European Social Fund.

Between May 2005 and March 2006, the accused set up 19 commercial companies, in which they assumed the role of partners and managers. Nine of those companies received no subsidies. The ten other companies, by contrast, obtained subsidies totalling EUR 750 613.79, of which EUR 654588.34 was actually paid, including EUR 279 272.18 from the budget of the European Union.

Following the payment of the subsidies in question, the accused transferred their shares in the companies concerned to a third party, then those companies ceased trading. At the time when criminal proceedings were brought against the accused, the company assets were no longer on the premises of those companies, which were automatically removed from the register of companies.

During the period in which the subsidies in question were paid, the commercial companies concerned employed a total of 107 disabled persons, in respect of whom those companies duly discharged their obligations as regards wages and social security contributions. However, those employees' work did not contribute to the objectives set out in the applications for subsidies. According to an expert's report, the work was fictitious.

The accused managed the companies in question centrally from one of the companies situated in Košice (Slovakia), at the same address as the permanent residence of the accused. In each of those companies, the accused appointed an employee to the position of director.

The referring court notes that only the companies to which a subsidy was actually awarded and paid, that is, ten companies in total, are the subject of the charge.

Criminal proceedings were brought against the defendants in their capacity as partners and managers of those companies on the basis of the charge brought by Slovak Office of the Special Prosecutor's Office of the General Prosecutor's Office of the Slovak Republic (Úrad špeciálnej prokuratúry Generálnej prokuratúry Slovenskej republiky). The district offices for labour, social affairs and family as injured parties in the main proceedings, sought damages from the accused during the investigation, in the amount of the subsidy actually paid.

However, the referring court considers that, in the light of the case-law of the Supreme Court of the Slovak Republic (Najvyšši súd Slovenskej republiky), Article 46 of the Code of Criminal Procedure does not permit it, in criminal proceedings, to hear and determine the right of State bodies to compensation. On 29 November 2017, the Criminal Chamber of the Supreme Court of the Slovak Republic (Najvyšši súd Slovenskej republiky) issued an opinion in which it stated that: 'State material rights under the rules relating to the various types of taxes, which are initially decided by the competent 
administrative authority, in accordance with the procedure laid down in the Tax Code ... including material rights arising from an unjustified claim made by a taxable person for repayment of value added tax or excise duty, are administrative in nature and decisions on them are subject to review by an administrative court[;] those rights do not allow damages to be claimed in the context of criminal proceedings in accordance with Article 46(3) of the Code of Criminal Procedure ... . Thus, no overlap is possible, that is to say no conflict of jurisdiction between the different institutions (administrative and judicial), nor a duplication of decisions on the same right.' The Supreme Court of the Slovak Republic (Najvyšši súd Slovenskej republiky) also stated that those legal considerations apply mutatis mutandis 'to any other material right which, by virtue of its substantive basis (that is to say, the provision of law governing that right), does not constitute a right to compensation for damage or 'non-material' damage.

The Supreme Court of the Slovak Republic (Najvyšši súd Slovenskej republiky) then applied that case-law in criminal proceedings concerning offences affecting the financial interests of the European Union and offences of subsidy fraud. The referring court therefore assumes that it will also apply that case-law in the event of an appeal against its judgment in the main proceedings.

The referring court notes that the application of that case-law in the main proceedings could have the effect of preventing the State from bringing an action for compensation for damage caused by fraud. An administrative procedure referred to in the case-law of the Supreme Court of the Slovak Republic (Najvyšši súd Slovenskej republiky) can be directed only against the beneficiary of subsidy in question. The main proceedings concern commercial companies which no longer hold any assets and which were even removed from the register of companies. Such a procedure therefore does not enable the recovery of wrongly paid subsidies. By contrast, bringing an action for damages in the context of criminal proceedings brought against natural persons, in the present case the partners and managers of those commercial companies, can lead to the remedies claimed by the State.

In addition to that question, the national court asks whether de minimis aid granted in the form of assistance should be assessed individually, for each company, or as a whole, because of their centralised management. Finally, the referring court asks whether, in the present case, the total amount of the wrongly paid subsidy should be regarded as damage or whether, from that amount, it is necessary to deduct the costs which, admittedly, were incurred lawfully, but solely in order to conceal the fraud, delay the detection of the fraud and thus obtain the full amount granted.

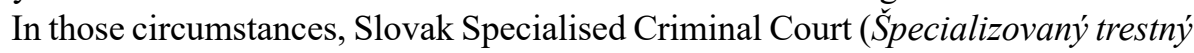
súd), taking the view that an interpretation of EU law is necessary in the main proceedings, decided to stay the proceedings and to refer the following questions to the Court of Justice for a preliminary ruling: ${ }^{20}$

20 Request for a preliminary ruling from the Specialised Criminal Court (Špecializovaný trestný súd) (Slovakia) lodged on 9 August 2019 - Slovak Office of the Special Prosecutor's Office of the General Prosecutor's Office of the Slovak Republic (Úrad špeciálnej prokuratúry Generálnej prokuratúry Slovenskej republiky) versus TG and UF (Case C-603/19). 
1. Is the Directive $2012 / 29 / \mathrm{EU}$ on victims of crime (principally the right of the injured party to participate actively in criminal proceedings and the right to secure compensation for damage in criminal proceedings) applicable, as regards rights which, by their nature, are not enjoyed solely by a natural person, as a sentient being, also to legal persons and the State, or State authorities, where the provisions of national law confer on them the status of injured party in criminal proceedings?

2. Are legislation and decision-making practices, such that the State may not claim compensation in criminal proceedings for the damage caused to it by fraudulent conduct on the part of an accused person resulting in the misappropriation of funds from the budget of the European Union, or may not appeal, under Article 256(3) of the Code of Criminal Procedure, against the order by which the court decides not to admit it, or not to admit the authority representing it, to the main proceedings to seek compensation for the damage as an injured party, and it does not have any other type of procedure available to it by which it may assert its right as against the accused, which means that it is also not possible to guarantee its right to compensation for damage against the property and property rights of the accused under Article 50 of the Code of Criminal Procedure, thus rendering that right de facto unenforceable, compatible with Articles 17 and 47 of the Charter of Fundamental Rights of the European Union, Article 325 of the Treaty on the Functioning of the European Union and Article 38(1) (h) of the Regulation (EC) No 1260/1999 laying down general provisions on the Structural Funds, read in conjunction with Regulation (EC) No 1681/94 concerning irregularities and the recovery of sums?

3. Is the concept of 'the same undertaking' referred to in Article 2 of Regulation (EC) No 994/98 on the application of Articles 92 and 93 of the Treaty establishing the European Community to certain categories of horizontal State aid, read in conjunction with Article 2(2) of the Regulation (EC) No 69/2001 on the application of Articles 87 and 88 Treaty establishing the European Community to de minimis aid, to be interpreted only formally as meaning that it is necessary and sufficient to establish whether the companies concerned have separate legal personality under national law, such that it is possible to grant to each of those companies State aid of up to EUR 100 000, or is the decisive criterion the actual mode of operation and management of those companies, held by the same persons and inter-related, in the manner of a system of branches managed by a central company, even though each has its own legal personality under national law, so that they must be deemed to form 'the same undertaking' and, as a single entity, may receive State aid of up to EUR 100000 only once?

4. For the purposes of the Convention on the protection of the European Communities' financial interests or the Directive (EU) 2017/1371 on the fight against fraud to the Union's financial interests by means of criminal law, does the term 'damage' mean only that part of the funds wrongly obtained which is directly related to the fraudulent conduct, or also the costs actually incurred and duly proven and the use of the assistance, if the evidence shows that their expenditure was necessary to conceal the fraudulent conduct, delay the detection of the fraudulent conduct and obtain the full amount of the State aid granted? 


\subsection{Consideration of the Questions by the Court of Justice}

As a preliminary point, it should be noted that, according to the Court's settled case-law, the procedure provided for by Article 267 of the Treaty on the Functioning of the European Union is an instrument for co-operation between the Court and national courts by means of which the Court provides national courts with the criteria for the interpretation of European Union law which they need in order to decide the disputes before them (see, inter alia, judgment in case C-370/12, Pringle, paragraph 83 and the case-law cited).

In the context of the co-operation between the Court and the national courts provided for in Article 267 of the Treaty on the Functioning of the European Union, it is solely for the national court, before which the dispute has been brought and which must assume responsibility for the subsequent judicial decision, to determine in the light of the particular circumstances of the case both the need for a preliminary ruling in order to enable it to deliver judgment and the relevance of the questions which it submits to the Court. Consequently, where the questions submitted concern the interpretation of EU law, the Court is, in principle, bound to give a ruling (judgment in case, C-268/17, $A Y$, paragraph 24 and the case-law cited).

It follows that questions on the interpretation of EU law referred by a national court in the factual and legislative context which that court is responsible for defining and the accuracy of which is not a matter for this Court to determine, enjoy a presumption of relevance. The Court may refuse to rule on a question referred by a national court only where it is quite obvious that the interpretation of EU law that is sought is unrelated to the actual facts of the main action or its object, where the problem is hypothetical, or where the Court does not have before it the factual or legal material necessary to give a useful answer to the questions submitted to it (judgment in case, C-268/17, AY, paragraph 25 and the case-law cited).

Thus, since the order for reference serves as the basis for the procedure followed before the Court, it is essential that the national court should, in that decision, set out the factual and legislative context of the dispute in the main proceedings and give at the very least some explanation of the reasons for the choice of the EU law provisions which it seeks to have interpreted and of the link it establishes between those provisions and the national legislation applicable to the proceedings pending before it (see, to that effect, inter alia, judgments in cases C-320/90 to C-322/90, Telemarsicabruzzo and Others, paragraph 6, and case C-406/15, Milkova, paragraph 73).

Those cumulative requirements concerning the content of a request for a preliminary ruling are set out explicitly in Article 94 of the Rules of Procedure of the Court of Justice and are also set out, in particular, in the Recommendations of the Court of Justice of the European Union to national courts and tribunals in relation to the initiation of preliminary ruling proceedings. The third indent of paragraph 15 of those recommendations states that the request for a preliminary ruling must contain 'a statement of the reasons which prompted the referring court or tribunal to inquire about the interpretation or validity of certain provisions of EU law, and the relationship between those provisions and the national legislation applicable to the main proceedings'.

It is in the light of those principles that the Court must examine the admissibility of the third and fourth questions. 
By its third question, the referring court asks, in essence, how it should interpret the concept of 'the same undertaking' in Article 2 of the Regulation (EC) No 994/98 on the application of Articles 92 and 93 of the Treaty establishing the European Community to certain categories of horizontal State aid, read in conjunction with Article 2(2) of the Regulation (EC) No 69/2001 on the application of Articles 87 and 88 Treaty establishing the European Community to de minimis aid, in order to assess whether there has been any circumvention of the law applicable to State aid in the dispute in the main proceedings.

The Slovak Government considers that the third question is inadmissible in so far as it is manifestly unrelated to the subject matter of the main proceedings. The Office of the Special Prosecutor argues that that question is inadmissible on the ground that it is hypothetical and unfounded.

In the present case, the dispute in the main proceedings concerns a ruling on the possible criminal liability of persons prosecuted for offences and, where applicable, those persons' obligation to make good the damage caused to the State in the event that they are held liable.

However, the order for reference does not explain why the referring court considers that an interpretation of the concept of 'the same undertaking' in Article 2 of the Regulation (EC) No 994/98 on the application of Articles 92 and 93 of the Treaty establishing the European Community to certain categories of horizontal State aid, read in conjunction with Article 2(2) of the Regulation (EC) No 69/2001 on the application of Articles 87 and 88 Treaty establishing the European Community to de minimis aid, is necessary for the purposes of deciding the dispute pending before it.

The third question is therefore inadmissible.

By its fourth question, the referring court asks, in essence, whether the concept of 'damage', within the meaning of the Convention on the protection of the European Communities' financial interests and the Directive (EU) 2017/1371 on the fight against fraud to the Union's financial interests by means of criminal law, must include costs actually incurred and duly proven, and the use of the financial assistance, if it is established that those costs were necessary to conceal fraudulent conduct, delay the detection of the fraud and obtain all the State aid in question.

The Slovak Government submits that that question is inadmissible, given that the order for reference does not contain the factual and legal information which would enable the Court to give a useful answer to that question.

Without expressly raising a plea of inadmissibility, both the Office of the Special Prosecutor and the Commission point out that the order for reference does not refer to any specific provision of the Convention on the protection of the European Communities' financial interests or of the Directive (EU) 2017/1371 on the fight against fraud to the Union's financial interests by means of criminal law.

In that regard, it must be noted that the order for reference does not specify which national provisions are applicable to the dispute in the main proceedings, nor does it give any indication of the reasons for choosing the rules of EU law of which the referring court seeks an interpretation or why an answer to the fourth question might affect the outcome of that dispute. 
Thus, by asking the Court of Justice, in essence, to define the concept of 'damage' in the light of the Convention on the protection of the European Communities' financial interests, which does not state that term, or in the light of the Directive (EU) 2017/1371 on the fight against fraud to the Union's financial interests by means of criminal law, which is not applicable to the main proceedings since it is subsequent to the facts in question, without referring to any national provision whatsoever or giving any indication as to how it intends to use that answer, the referring court has not provided the Court of Justice with the necessary factual and legal information which would enable it to give a useful answer to the questions referred.

The fourth question is therefore inadmissible.

By its first question, the referring court asks, in essence, whether Article 2(1) of the Directive 2012/29/EU on victims of crime must be interpreted as meaning that that directive also applies to legal persons and the State, in so far as national law confers on them the status of 'injured party' in criminal proceedings.

In that respect, it should be noted that, in accordance with Article 1(1) of the Directive 2012/29/EU on victims of crime, the purpose of that directive is to provide certain guarantees to victims of crime. Article 2(1) of that directive defines as a 'victim', within the meaning of Article 1, a natural person who has suffered harm, including physical, mental or emotional harm or economic loss which was directly caused by a criminal offence, and family members of a person whose death was directly caused by a criminal offence and who have suffered harm as a result of that person's death.

Such wording clearly does not permit the inclusion of legal persons within the scope of that directive.

The answer to the first question is, therefore, that Article 2(1) of the Directive 2012/29/EU on victims of crime must be interpreted as meaning that that directive does not apply to legal persons or to the State, even if national law confers on them the status of injured party in criminal proceedings.

By its second question, the referring court asks, in essence, whether Article 325 of the Treaty on the Functioning of the European Union must be interpreted as precluding provisions of national law, as interpreted in national case-law, under which, in criminal proceedings, the State may not claim compensation for damage caused to it by fraudulent conduct on the part of the accused person resulting in the misappropriation of funds from the budget of the European Union, and under which the State does not have, in those proceedings, any other type of action available to it by which it may assert its right as against the accused.

As a preliminary point, it should be noted that, according to the Court's case-law, Article 325(1) and (2) of the Treaty on the Functioning of the European Union obliges the Member States to counter illegal activities affecting the financial interests of the European Union through effective deterrent measures and, in particular, obliges them to take the same measures to counter fraud affecting the financial interests of the European Union as they take to counter fraud affecting their own interests (judgment in case C-617/10, Akerberg Fransson, paragraph 26 and the case-law cited).

In that regard, the Court has already held that the Member States have freedom to choose the applicable penalties, which may take the form of administrative penalties, criminal penalties or a combination of the two, whilst specifying that, in cases of serious 
fraud, criminal penalties may nevertheless be essential (see, to that effect, judgment in case C-105/14, Taricco and Others, paragraph 39).

Member States therefore have a precise obligation as to the result to be achieved that is not subject to any condition regarding the application of the rule laid down in Article 325(1) and (2) of the Treaty on the Functioning of the European Union. Those provisions therefore have the effect, in accordance with the principle of the precedence of EU law, in their relationship with the domestic law of the Member States, of rendering automatically inapplicable, merely by their entering into force, any conflicting provision of national law (see to that effect, judgment case C-105/14, Taricco and Others, paragraphs 51 and 52).

In the present case, the referring court raises the question, more specifically, of the compatibility with the obligations arising from Article 325 of the Treaty on the Functioning of the European Union of national rules of criminal procedure as interpreted in national case-law which, in a case such as that in the main proceedings, do not allow the State to be accorded a right to compensation as the injured party in the criminal proceedings.

The referring court notes, however, that the State could recover the wrongly paid sums by bringing administrative proceedings for breach of financial discipline, within the meaning of Article 31 of Act No. 523/2004 Coll. on Financial Rules Governing the Budget of Public Administrative Authorities (zákon č. 523/2004 Z. z. o rozpočtových pravidlách verejnej správy). That court explains that, in accordance with that provision, the grant or use of public funds for purposes other than those laid down for those funds constitutes a breach of financial discipline. However, again according to the referring court, administrative proceedings enable repayment of the wrongly paid financial assistance to be demanded only from the formal beneficiary of the subsidy, namely, in this case, legal persons.

In its written observations, the Slovak Government argues that, under national law, it is also possible for the State to bring not only a civil action against the legal person to which the assistance was wrongly paid, but also to obtain, following a criminal conviction, compensation from the convicted natural person for the damage suffered.

In that context, it is important to note that, under Article 325(1) of the Treaty on the Functioning of the European Union, in order to counter illegal activities affecting the financial interests of the Union, Member States must adopt effective deterrent measures which are equivalent to those taken at national level to counter fraud affecting the interests of the Member State concerned.

As the Commission noted, Member States are in particular required to take effective measures to recover sums wrongly paid to the beneficiary of a subsidy funded in part from the budget of the European Union. On the other hand, Article 325 of the Treaty on the Functioning of the European Union does not impose on Member States any constraint, other than that relating to the effectiveness of the measures, as regards the procedure which must enable such an outcome to be achieved, so that the Member States have some leeway in that respect, subject to observing the principle of equivalence.

In that regard, it should be noted at the outset that the coexistence of different legal remedies with different objectives specific to administrative law, civil law or criminal law, cannot, in itself, undermine the effectiveness of the fight against fraud affecting 
the financial interests of the European Union, provided that the national legislation, as a whole, enables the recovery of wrongly paid assistance from the Union budget.

In the present case, the referring court raises more specifically the question of compliance with the obligation of effectiveness laid down in Article 325 of the Treaty on the Functioning of the European Union, in the event that the State is not granted a right to compensation, as the injured party, in the context of criminal proceedings, and where the administrative proceedings allow the recovery of wrongly paid financial assistance only from the legal person which received that assistance.

In that regard, it should be noted, first, that the non-recognition of a State's right to compensation as an injured party in criminal proceedings cannot, in itself, be contrary to the obligations under Article 325 of the Treaty on the Functioning of the European Union.

Although criminal penalties may be essential to enable Member States to combat certain cases of serious fraud in an effective and dissuasive manner (judgments case C-105/14, Taricco and Others, paragraph 39, and case C-42/17, M.A.S. and M.B., paragraph 34 ), such penalties are required in order to ensure that national law is dissuasive and are not intended to permit the recovery of sums paid but not due.

Second, it follows that the existence in the legal order of the Member State concerned of an effective remedy for acts affecting the financial interests of the European Union, whether in the context of criminal, administrative or civil proceedings, is sufficient to satisfy the obligation of effectiveness laid down by Article 325 of the Treaty on the Functioning of the European Union provided that that remedy allows the recovery of wrongly paid assistance and provided that criminal penalties make it possible to combat cases of serious fraud.

That is the case here, provided that, which it is for the referring court to verify, the State has the option, according to the applicable national law, of bringing, first, administrative proceedings enabling it to obtain the recovery of the assistance wrongly paid to the legal person and, second, civil proceedings not only to establish the civil liability of the legal person which received the wrongly paid assistance, but also to obtain, following a criminal conviction, compensation from the convicted natural person for the damage suffered.

\subsection{Rulings}

The Court of Justice in answer to the questions referred to it rules:

1. Article 2(1) of the Directive 2012/29/EU on victims of crime must be interpreted as meaning that that directive does not apply to legal persons or to the State, even if national law confers on them the status of injured party in criminal proceedings.

2. Article 325 of the Treaty on the Functioning of the European Union must be interpreted as not precluding provisions of national law, as interpreted in national case-law, under which, in criminal proceedings, the State may not claim compensation for damage caused to it by fraudulent conduct on the part of the accused person resulting in the misappropriation of funds from the budget of the European Union, and under which the State does not have, in those proceedings, any other type of action available to it by which it may assert its right as against 
the accused, provided that, which it is for the referring court to verify, the national legislation provides for effective proceedings for the recovery of assistance wrongly received from the budget of the European Union.

\section{Order of 1 October 2019 - Case C-495/18, $Y X$ (Rejected)}

\subsection{Reference for a Preliminary Ruling}

The request for a preliminary ruling concerns the interpretation of Article 4(1) (a) and (2), and Article 9(1)(b) of the Framework Decision 2008/909/JHA on mutual recognition of custodial sentences and deprivation of liberty.

The request has been made in proceedings relating to the recognition and enforcement in Slovakia of a criminal judgment handed down by a Czech court imposing on YX, a Slovak national, a custodial sentence of 5 years for offences of 'withholding taxes, charges and other similar compulsory payments'.

\subsection{Dispute in the Main Proceedings and the Questions Referred for a Preliminary Ruling}

By decision of 10 November 2014 of Czech Regional Court in Ústi nad Labem (Krajský soud v Ústi nad Labem) confirmed by decision of 27 February 2015 of the Vrchní soud v Praze (High Court, Prague, Czech Republic), YX, a Slovak national, was given a custodial sentence of 5 years for tax offences ('the judgment at issue').

On 16 October 2017, Slovak Regional Court in Trenčín (Krajský súd v Trenčine) received from the Regional Court in Ústi nad Labem (Krajský soud v Ústi nad Labem) the judgment at issue, together with the certificate referred to in Annex I to the Framework Decision 2008/909/JHA on mutual recognition of custodial sentences and deprivation of liberty.

By decision of 6 December 2017, the Regional Court in Trenčín (Krajský súd $v$ Trenčine) recognised the judgment at issue.

YX lodged an appeal against that decision before the referring court, the Supreme Court of the Slovak Republic (Najvyšši súd Slovenskej republiky). In support of his appeal, he claimed that, since 2015, he has been living in the Czech Republic, proof of which he could have provided had he been informed of the proceedings before the Regional Court in Trenčín (Krajský súd v Trenčine), so that the place of his habitual residence would not have been determined as being in the Slovak Republic.

The referring court states that it is apparent from the population register of the Slovak Republic that, since 22 October 1986, YX's permanent residence has been registered in the territory of that Member State. It also states that, under the relevant provisions of national law, the permanent or temporary residence of a Slovak national in the territory of the Slovak Republic is purely for record-keeping purposes and is not conditional upon the citizen actually living there or having family, social, professional or other ties to that territory. Thus a decision of another Member State imposing a custodial sentence may be recognised and enforced in Slovakia if the convicted Slovak national has his permanent or temporary residence there, in formal terms even if he is not actually living in Slovak territory.

In those circumstances, the Supreme Court of the Slovak Republic (Najvyšši súd 
Slovenskej republiky) decided to stay the proceedings and to refer the following questions to the Court of Justice for a preliminary ruling: ${ }^{21}$

1. Is Article 4(1)(a) of the Framework Decision 2008/909/JHA on mutual recognition of custodial sentences and deprivation of liberty to be interpreted to the effect that the criteria set out therein are satisfied only when the sentenced person has, in the Member State of his nationality, such family, social, professional or other ties that it is possible to assume reasonably from those ties that enforcement in that State of the sentence may facilitate his social rehabilitation, and as therefore precluding national legislation such as Paragraph 4(1)(a) of the Act No. 549/2011 Coll. on the Recognition and Enforcement of Decisions Imposing Criminal Sanction Involving Deprivation of Liberty in the European Union (zákon č. 549/2011 Z. z. o uznávaní a výkone rozhodnutí, ktorými sa ukladá trestná sankcia spojená s odňatím slobody v Európskej únii) which, in such cases, enables a judgment to be recognised and enforced in the event of merely formally recorded habitual residence in the executing State, regardless of whether the sentenced person has concrete ties in that State which could enhance his social rehabilitation?

2. If that question is answered in the affirmative, is Article 4(2) of the Framework Decision 2008/909/JHA on mutual recognition of custodial sentences and deprivation of liberty to be interpreted to the effect that the competent authority of the issuing State is required also in the situation provided for in Article 4(1) (a) of that framework decision to satisfy itself, even before forwarding the judgment and certificate, that enforcement of the sentence by the executing State would serve the purpose of facilitating the social rehabilitation of the sentenced person and is, furthermore, required to provide the information gathered for that purpose in section (d), point 4, of the certificate specifically, where the sentenced person claims in the statement of his opinion provided for in Article 6(3) of that framework decision that he has concrete family, social or professional ties in the issuing State?

3. If question 1 is answered in the affirmative, must Article 9(1)(b) of the Framework Decision 2008/909/JHA on mutual recognition of custodial sentences and deprivation of liberty be interpreted to the effect that where, in the situation set out in Article 4(1)(a) of that framework decision, despite the consultation under Article 4(1)(3) of that framework decision and any provision of other necessary information, it is not proven that there are such family, social or professional ties from which it could reasonably be assumed that the enforcement in the executing State of the sentence may facilitate the social rehabilitation of the sentenced person, there is still a ground for refusing to recognise and enforce the judgment?

\subsection{Developments Since the Request for a Preliminary Ruling Was Made}

By letters of 4 June 2019, the referring court and the Czech Government informed

21 Request for a preliminary ruling from the Supreme Court of the Slovak Republic (Najvyšši súd Slovenskej republiky) (Slovak Republic) lodged on 30 July 2018 - YX (Case C-495/18). 
the Court that the Regional Court in Ústi nad Labem (Krajský soud v Ústi nad Labem) had withdrawn its request for recognition of the judgment at issue. The Czech Government also informed the Court that enforcement of the sentence in the Czech Republic was ordered and that YX has been serving his sentence in a prison of that Member State since 4 March 2019.

In addition, the referring court announced that it does not wish to withdraw its request for a preliminary ruling on the ground that the Court's judgment in the present case might be relevant for the decision in another case pending before it.

In the light of that information, the Court, by letter of 11 June 2019, asked the referring court, first, to confirm whether it is still dealing with the dispute in which it submitted its request for a preliminary ruling and, second, to indicate whether it has retained that case.

By letter of 27 June 2019, received at the Court Registry on 4 July 2019, the referring court informed the Court that the proceedings which gave rise to its request for a preliminary ruling have been stayed pending the judgment of the Court. The referring court also confirmed that it was not withdrawing that request for a preliminary ruling on the ground that 'the judgment to be delivered is important for the decision to be handed down in another case before [it], which contains the same matters of fact and law and in which the proceedings have been stayed ... pending the judgment of the Court in the present case'.

\subsection{Reference for a Preliminary Ruling}

According to settled case-law of the Court, the procedure provided for by Article 267 of the Treaty on the Functioning of the European Union is an instrument for co-operation between the Court and national courts by means of which the Court provides national courts with the criteria for the interpretation of EU law which they need in order to decide the disputes before them (order in case C-169/18, Mahmood and Others, paragraph 21 and the case-law cited).

It is thus clear, from both the wording and the scheme of Article 267 of the Treaty on the Functioning of the European Union, that the preliminary ruling procedure presupposes that a dispute is actually pending before the national courts in which they are called upon to give a decision which is capable of taking account of the preliminary ruling (see, inter alia, orders in case C-252/11, Sujetová, paragraph 14, and case C-537/15, Euro Bank, paragraph 32).

The justification for a reference for a preliminary ruling is not that it enables advisory opinions on general or hypothetical questions to be delivered, but rather that it is necessary for the effective resolution of a dispute (see, inter alia, orders in case C-252/11, Šujetová, paragraph 15, and case C-537/15, Euro Bank, paragraph 33).

In the present case, it is apparent from the request for a preliminary ruling that the dispute in the main proceedings concerns the decision of the Regional Court in Trenčín (Krajský súd v Trenčine) to recognise and declare as enforceable in Slovak territory the judgment at issue which was forwarded to it by the Regional Court in Ústi nad Labem (Krajský soud v Ústi nad Labem), together with the certificate referred to in Annex I to the Framework Decision 2008/909/JHA on mutual recognition of custodial sentences and deprivation of liberty. 
In that regard, it should be observed that, under Article 13 of the Framework Decision 2008/909/JHA on mutual recognition of custodial sentences and deprivation of liberty, after the certificate referred to in Annex I thereto is withdrawn, the Member State of enforcement no longer enforces the sentence.

It is apparent from the letters sent to the Court on 4 and 27 June 2019 that the Regional Court in Ústi nad Labem (Krajský soud v Ústi nad Labem) withdrew its request for recognition of the judgment at issue and that, since 4 March 2019, the sentence pronounced against YX is being enforced in the issuing Member State.

Therefore, it must be held that, following that withdrawal, there is no need to adjudicate on the action.

It follows that the questions referred for a preliminary ruling are now hypothetical and that the conditions enabling the Court to proceed with the reference are no longer satisfied.

In those circumstances, there is no need to adjudicate on the request for a preliminary ruling.

That finding is without prejudice to the possibility or, as the case may be, the obligation for the referring court to make a fresh request for a preliminary ruling to the Court of Justice under Article 267 of the Treaty on the Functioning of the European Union, if it considers that such a decision is necessary to resolve a dispute before it and in the context of which, in its opinion, the same questions of interpretation of EU law arise.

\section{Bibliography:}

- Judgment of the Court of Justice of the European Union of 1 October 2020 - case C-603/19, TG and UF

- Judgment of the Court of Justice of the European Union of 11 January 2017 - case C-289/15, Jozef Grundza

- Judgment of the Court of Justice of the European Union of 22 December 2008 case C-491/07, Vladimir Turanský

- KLIMEK, L. - KLÁTIK, J. - SAKTOROVÁ, L'. - MIHÓK, M. 2021. Recognition of Foreign Criminal Sanctions. Prague : Leges, 2021, 240 pages

- KLIMEK, L. (ed.) 2021. Európske mechanizmy uznávania sankcií spojených s odñatím slobody v teórii a praxi [transl.: European Mechanisms of Recognition of Sanctions Involving Deprivation of Liberty in Theory and Practice]. Brno : Tribun EU, 2021, 739 pages

- KLIMEK, L. (ed.) 2018. Judikatúra Súdneho dvora Európskej únie vo veciach trestných [transl.: Case-law of the Court of Justice of the European Union in Criminal Matters]. Bratislava : Wolters Kluwer, 2018, 392 strán

- KLIMEK, L. (ed.) 2020. Trestné právo Európskej únie v teórii a praxi [transl.: European Union Criminal Law in Theory and Practice]. Brno : Tribun EU, 2020, 957 pages

- KLIMEK, L. 2017. Mutual Recognition of Judicial Decisions in European Criminal Law. Cham : Springer, 2017, 742 pages

- KLIMEK, L. 2017. Základy trestného práva Európskej únie [transl.: Fundamentals of the European Union Criminal Law]. Bratislava : Wolters Kluwer, 2017, 264 pages

- KLIMEK, L. 2021. Zákon o uznávaní a výkone rozhodnutí, ktorými sa ukladá trestná sankcia spojená s odňatím slobody v Európskej únii: Komentár [transl.: Act on the Recognition and Enforcement of Decisions Imposing Criminal Sanction Involving 
Deprivation of Liberty in the European Union: Commentary]. Bratislava : Wolters Kluwer, 2021, 666 pages

- Opinion of Advocate General Bobek delivered on 28 July 2016 - Case C-289/15 - Grundza

- Order of the Court of Justice of the European Union of 1 October 2019 - case C-495/18, $Y X$

- Reference for a preliminary ruling from the Regional Court for Criminal Matters (Landesgericht für Strafsachen) (Austria), lodged on 31 October 2007 - Criminal proceedings against Vladimír Turanský (Case C-491/07)

- Request for a preliminary ruling from the District Court in Prešov (Krajský súd v Prešove) (Slovak Republic) lodged on 15 June 2015 - Jozef Grundza (Case C-289/15)

- Request for a preliminary ruling from the Specialised Criminal Court (Špecializovaný trestný súd) (Slovakia) lodged on 9 August 2019 - Slovak Office of the Special Prosecutor's Office of the General Prosecutor's Office of the Slovak Republic (Úrad špeciálnej prokuratúry Generálnej prokuratúry Slovenskej republiky) versus TG and UF (Case C-603/19)

- Request for a preliminary ruling from the Supreme Court of the Slovak Republic (Najvyšši súd Slovenskej republiky) (Slovak Republic) lodged on 30 July 2018 YX (Case C-495/18)

\section{Summary: Criminal Cases Related to Slovak Citizens before the Court of Justice of the European Union}

Slovak national criminal law has constantly been influenced by the European Union law. Not only legislation, but also case-law of the Court of Justice of the European Union shall be accepted in the Member States. As regards case-law, some proceedings before the Court of Justice have been connected to Slovak citizens, in particular citizens staying in another States and committing criminal offence(s). The objective of the work is the assessment of case-law of the Court of Justice of the European Union as regards Slovak citizens within criminal cases. It is divided into four sections. The first section analyses case C-491/07 - Vladimir Turanský. The second section analyses case C-289/15 - Jozef Grundza. The third section analyses case C-603/19 - TG and UF. The fourth section analyses case C-495/18, $Y X$. In each section at the outset is emphasised the subject matter of the analysed case. As a starting point for further analysis, one may usefully look the dispute in the proceedings. There are introduced questions(s) referred to the Court of Justice. Further, there is examined the legal opinion of the Court of Justice. Each analysis is concluded by the Court's rulings.

doc. JUDr. et PhDr. mult. Libor Klimek, PhD. Matej Bel University in Banská Bystrica Faculty of Law, Department of Criminal Law Komenského 20, 97401 Banská Bystrica Slovak Republic e-mail: libor.klimek@umb.sk 
doc. JUDr. Eva Szabová, PhD.

Trnava University in Trnava

Faculty of Law, Department of Criminal Law and Criminology

Hornopotočná 23, 91843 Trnava

Slovak Republic

e-mail: eva.szabova@truni.sk

doc. JUDr. Simona Ferenčíková, PhD.

Pavol Jozef Šafárik University in Košice

Faculty of Law, Department of Criminal Law

Kováčska 26, P.O.BOX A-45, 04075 Košice

Slovak Republic

e-mail: simona.ferencikova@upjs.sk 